\title{
Effect of Planting Pattern and Population Density on Yield and Quality of the Horn- Type Maricongo Plantain (Musa acuminata $\times$ M. balbisiana, AAB) in North-Central Puerto Rico ${ }^{1,2}$
}

\author{
Héber Irizarry, Edmundo Rivera, José A. Rodríguez, and \\ José J. Green ${ }^{3}$
}

\begin{abstract}
The effect of plant spacing on yields and quality of Maricongo plantains (Musa acuminata $\times M$. balbisiana, $A A B$ ) was determined in an Ultisol at the Corozal Substation. The highest yields, without detriment to bunch and fruit size, were obtained with 1,742 plants/acre $(4,303$ plants/ha) spaced at $5 \times 5 \mathrm{ft}(1.5 \times 1.5$ $\mathrm{m})$. At this spacing combined production of the plant and ratoon crops was 119,356 marketable fruits/acre, weiging 33.4 tons $(294,809$ fruits/ha weighing $73.5 \mathrm{t} / \mathrm{ha}$ ). Even assuming a $20 \%$ loss under commercial management, these yields represent a net production of 95,485 fruits/acre weighing 26.7 tons $(235,847$ fruits/ha weighing $58.7 \mathrm{t} / \mathrm{ha})$ over a 30 -month period.
\end{abstract}

\section{INTRODUCTION}

Plantains (Musa acuminata $\times$ M. balbisiana, AAB) are a staple food in the hot-humid tropics. The starchy green fruits contain about $40 \%$ carbohydrates and $6 \%$ protein, in addition to various vitamins and minerals. A ton of green fruit contains $1,200 \mathrm{lb}(545 \mathrm{~kg})$ of fresh pulp or 480 lb $(218 \mathrm{~kg})$ of dry pulp, with $364,800 \mathrm{cal}$.

Annual plantain consumption in Puerto Rico has been estimated at 65 lb (29.5 kg) per capita. Although about 250 million plantains are produced annually in Puerto Rico, imports are necessary to satisfy the local demand.

In Puerto Rico Vicente-Chandler and Figarella ${ }^{4}$ found that with rows of plantains $10 \mathrm{ft}(3.1 \mathrm{~m})$ apart, yields increased with closer spacings within the row down to $5 \mathrm{ft}(1.5 \mathrm{~m})$, equivalent to a population of 871

${ }^{1}$ Manuscript submitted to Editorial Board June 30, 1977.

${ }^{2}$ This paper covers work carried out cooperatively between the Agricultural Research Service, USDA, and the Agricultural Experiment Station, College of Agricultural Sciences, Mayagüez Campus, University of Puerto Rico, Río Piedras, P.R.

${ }^{3}$ Horticulturist and Agronomist, respectively, Agricultural Research Service, USDA; Assistant Agronomist and Research Assistant, respectively, Agricultural Experiment Station, College of Agricultural Sciences, Mayagüez Campus, University of Puerto Rico, Río Piedras, P.R.

${ }^{4}$ Vicente-Chandler, J., and Figarella, J., 1962. Experiments on plantain production with conservation in the mountain region of Puerto Rico, J. Agric. Univ. P.R., 46(3): 226-36. 
plants/acre (2,151 plants/ha.) Caro-Costas ${ }^{5}$ and more recently Irizarry et al. ${ }^{6}$ found that yields of marketable fruits and of total fruits increased with closer spacing down to $6 \times 5 \mathrm{ft}(1.8 \times 1.5 \mathrm{~m})$, equivalent to 1,452 plants/acre (3,586 plants/ha), without detriment to bunch or fruit size. In Colombia, García-Reyes et al. ${ }^{7}$ reported similar relationships to closer spacing when yields were compared from plants spaced at distances of $14.8 \times 14.8 \mathrm{ft}(4.5 \times 4.5 \mathrm{~m})$ and $5 \times 5 \mathrm{ft}(1.5 \times 1.5 \mathrm{~m})$ or 1,742 plants/acre (4,303 plants/ha).

The present study was undertaken to determine the maximum yield response of the Maricongo cultivar of plantains to close spacing, using both single and double planting systems.

\section{MATERIALS AND METHODS}

The experiment was planted in February 1974 at the Corozal Substation on a red, acid, deep, moderately-drained Corozal clay (Ultisol) with an exchange capacity of $12 \mathrm{meq} / 100 \mathrm{~g}$ and a $20 \%$ slope. The soil was limed to $\mathrm{pH} 5.8$ by broadcasting limestone at 2 tons/acre $(4.4 \mathrm{t} / \mathrm{ha})$.

Seven plant spacings were tested in an incomplete-block design with four replications. The planting patterns and densities were one plant/ hole spaced at $6 \times 6 \mathrm{ft}(1.8 \times 1.8 \mathrm{~m})$ or 1,210 plants/acre $(2,989$ plants/ ha), $5 \times 5 \mathrm{ft}(1.5 \times 1.5 \mathrm{~m})$ or 1,742 plants/acre $(4,303$ plants/ha), and 4 $\times 4 \mathrm{ft}(1.2 \times 1.2 \mathrm{~m})$ or 2,723 plants/acre $(6,726$ plants/ha); and two plants/ hole spaced at $10 \times 5 \mathrm{ft}(3.1 \times 1.5 \mathrm{~m})$ or 1,742 plants/acre $(4,303$ plants/ ha), $10 \times 4 \mathrm{ft}(3.1 \times 1.2 \mathrm{~m})$ or 2,178 plants/acre $(5,380$ plants/ha $), 6 \times 6$ ft $(1.8 \times 1.8 \mathrm{~m})$ or 2,420 plants/acre $(5,977$ plants/ha $)$, and $8 \times 4 \mathrm{ft}(2.4$ $\times 1.2 \mathrm{~m})$ or 2,723 plants/acre $(6,726$ plants/ha). These spacings were measured along the slope between the centers of the planting holes. After the plant crop was harvested, only one plant was allowed to develop in each hole. Each experimental plot had 12 to 30 plants, depending on the spacing, and was surrounded by border rows.

The propagating material (corms) was obtained from apparently virusfree plants with recorded yields of at least 40 marketable fruits/bunch. The corms were peeled and dipped for $5 \mathrm{~min}$ in a nematicide-insecticide solution of $11 \mathrm{ml} \mathrm{DBCP} 70-75 \mathrm{EC}^{8}$ and $25 \mathrm{ml}$ of aldrin/3.8 liters of water.

\footnotetext{
${ }^{5}$ Caro-Costas, R., 1968. Effect of plant population and distribution on yields of plantains, J. Agric. Univ. P.R., 52(3): 256-9.

${ }^{6}$ Irizarry, H., Green, J. J., and Hernández, I., 1975. Effect of plant density on yield and other quantitative characters of the Maricongo plantain (Musa acuminata $\times$ M. balbisiana, AAB), J. Agric. Univ. P.R., 59(4): 245-54.

${ }^{7}$ García-Reyes, F., Gallo-Cardona, A., and López-Alzate, R., 1975. Análisis económicos de distancias de siembra en plátano para dos localidades de la zona cafetera colombiana, Cenicafé, Colombia, 26(4): 161-71.

${ }^{8}$ This paper reports the results of research only. Mention of a pesticide in this paper does not constitute a recommendation by the USDA or the Agricultural Experiment Station of the University of Puerto Rico, nor does it imply registration under FIFRA.
} 
After corms were planted, nematodes and soil insects were controlled with applications of $10 \%$ granular Carbofuran at $28 \mathrm{~g} / \mathrm{plant}$ in single plantings and $56 \mathrm{~g} /$ plant in double plantings. Applications were made 7 weeks after planting and every 6 months thereafter. The plants were also sprayed with orchard mineral oil at 3.8 liters/acre (9.4 liters/ha) every 2 to 3 weeks to control Sigatoka, caused by Mycosphaerella musicola (Cercospora musae).

A 10-5-20 fertilizer supplemented with $166 \mathrm{lb}(75.3 \mathrm{~kg})$ of $\mathrm{MgO}$ and 100 $\mathrm{lb}(45.4 \mathrm{~kg})$ of minor elements/ton was applied at $2 \mathrm{lb}(0.9 \mathrm{~kg})$ and $1.4 \mathrm{lb}$ $(0.6 \mathrm{~kg}) /$ plant or plant set for the first and second (ratoon) crops, respectively. The plant crop was fertilized about 2, 5, and 9 months after planting, whereas the ratoon crop was fertilized 1 and 5 months after harvesting was completed and excess suckers had been removed.

Weeds were controlled with postemergence applications of paraquat at the rate of 2 pints/acre (2.3 liters/ha).

All bunches were harvested about 3.5 months after bunch-shooting and the number of marketable fruits, weight/bunch, and mean fruit weight in the third hand were determined.

\section{RESULTS AND DISCUSSION}

\section{PLANT CROP}

Monthly rainfall and temperatures at the Corozal Substation throughout the course of the experiment are shown in figure 1.

The bunch-shooting peaks for each plant spacing in a 3 month period are shown in figure 2. Plants spaced at $5 \times 5 \mathrm{ft}(1.5 \times 1.5 \mathrm{~m})$ and $6 \times 6 \mathrm{ft}$ $(1.8 \times 1.8 \mathrm{~m})$ in single plantings flowered earliest, with peaks from January through March 1975. Plants spaced at $4 \times 4 \mathrm{ft}(1.2 \times 1.2 \mathrm{~m})$ began to peak a month later, in February, and peaks lasted through April 1975. Bunch-shooting peaks in all double planting treatments were delayed until March through May 1975.

Harvesting began in April and ended abruptly on August 5, 1975, when gale-force winds that followed a 4-month drought (fig. 1) destroyed the planting. At that time, $50.1 \%$ of the experimental plants had been harvested, more from the single than from the double plantings.

Plants spaced at $6 \times 6 \mathrm{ft}(1.8 \times 1.8 \mathrm{~m})$ or 1,210 plants/acre $(2,989$ plants/ha) produced the heaviest bunches, which averaged $33.9 \mathrm{lb}$ (15.3 $\mathrm{kg}$ ) and 42 marketable fruits/bunch (table 1). These bunches were significantly heavier than those harvested in any of the other treatments. However, the mean number of fruits/bunch for this spacing was significantly higher only than that for plants spaced at $4 \times 4 \mathrm{ft}(1.2 \times 1.2 \mathrm{~m})$ and, in double planting, at $8 \times 4 \mathrm{ft}(2.4 \times 1.2 \mathrm{~m})$ and $10 \times 4 \mathrm{ft}(3.1 \times 1.2$ $\mathrm{m})$. Bunches from plants spaced at $5 \times 5 \mathrm{ft}(1.5 \times 1.5 \mathrm{~m})$ and, in double 
planting, at $6 \times 6 \mathrm{ft}(1.8 \times 1.8 \mathrm{~m})$ and $10 \times 5 \mathrm{ft}(3.1 \times 1.5 \mathrm{~m})$ did not differ significantly in number of fruits and weight.

As expected from the bunch-weight data, the heaviest individual fruits were also from the plants spaced at $6 \times 6 \mathrm{ft}(1.8 \times 1.8 \mathrm{~m}) 1,210$ plants/ acre $(2,989$ plants/ha) (table 1$)$. The mean fruit weight of $0.76 \mathrm{lb}(345 \mathrm{~g})$ for that spacing was significantly higher than that for any of the spacings

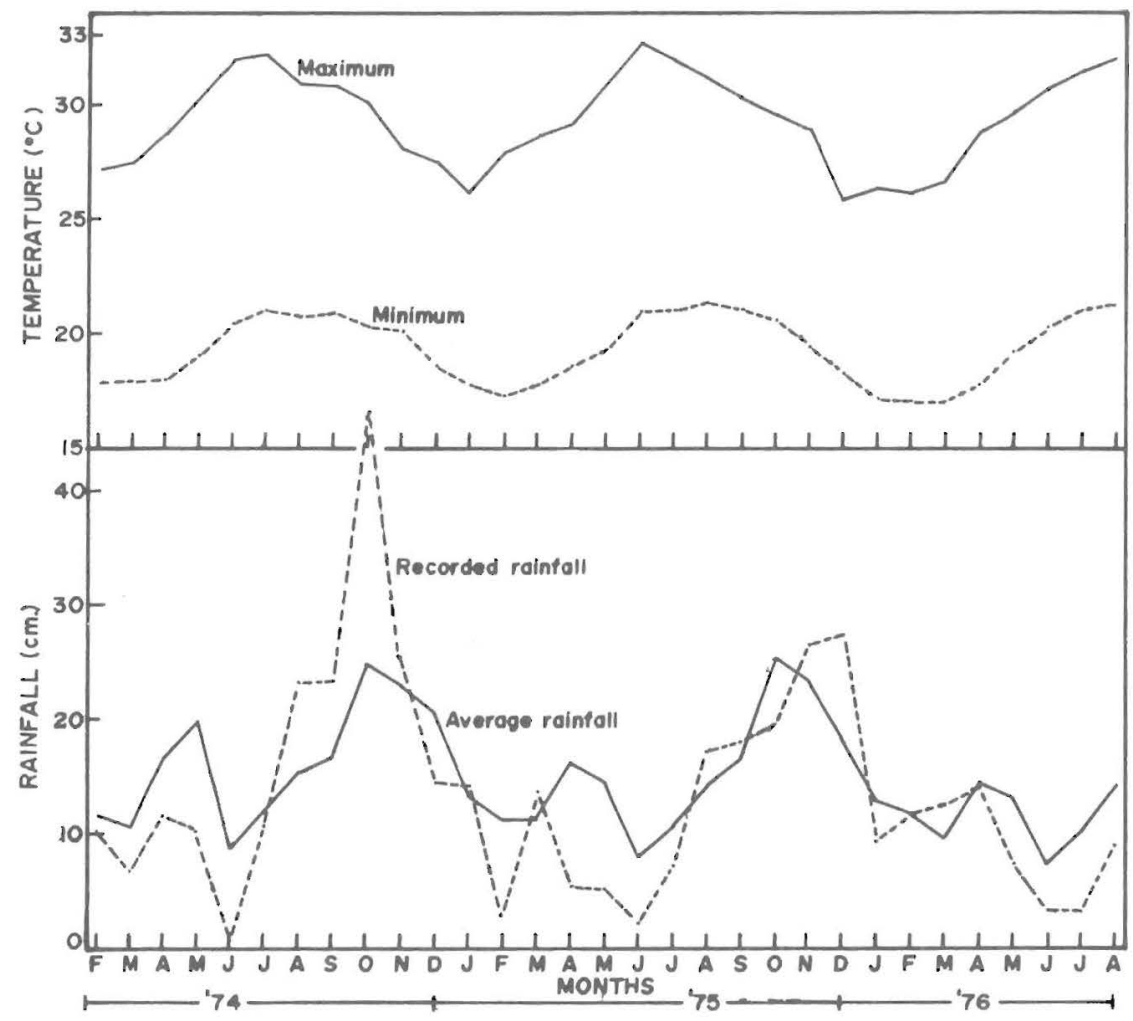

Fig. 1.-Monthly rainfall and maximum and minimum air temperatures recorded during the 30 -month experimental period at the Corozal Substation. The data on monthly average rainfall during the last decade were obtained from U.S. Department of Commerce, Climatological Data, Puerto Rico and the Virgin Islands.

except the $5 \times 5 \mathrm{ft}(1.5 \times 1.5 \mathrm{~m})$ and the $10 \times 5 \mathrm{ft}(3.1 \times 1.5 \mathrm{~m})$ or 1,742 plants/acre $(4,303$ plants/ha).

Comparisons between single and double plantings with equal plant densities [i.e., $5 \times 5 \mathrm{ft}(1.5 \times 1.5 \mathrm{~m})$ single vs. $10 \times 5 \mathrm{ft}(3.1 \times 1.5 \mathrm{~m})$ double, both equivalent to 1,742 plants/acre $(4,303$ plants/ha); and $4 \times 4$ $\mathrm{ft}(1.2 \times 1.2 \mathrm{~m})$ single vs. $8 \times 4 \mathrm{ft}(2.4 \times 1.2 \mathrm{~m})$ double, both equivalent to 
2,723 plants/acre $(6,726$ plants/ha) $]$ showed no significant differences in bunch and irruit characteristics (table 1).

The plants spaced at $4 \times 4 \mathrm{ft}(1.2 \times 1.2 \mathrm{~m})$ and $5 \times 5 \mathrm{ft}(1.5 \times 1.5 \mathrm{~m})$ and, in double planting, at $8 \times 4 \mathrm{ft}(2.4 \times 1.2 \mathrm{~m})$ produced the highest yields in terms of number of fruits: 64,889 to 79,114 fruits/acre $(160,275$ to 195,411 fruits/ha) (table 2 ). In addition to the plants spaced at $4 \times 4$ ft $(1.2 \times 1.2 \mathrm{~m})$ and $5 \times 5 \mathrm{ft}(1.5 \times 1.5 \mathrm{~m})$, those spaced at $6 \times 6 \mathrm{ft}(1.8$ $\times 1.8 \mathrm{~m}$ ) in both single and double plantings produced the highest yields

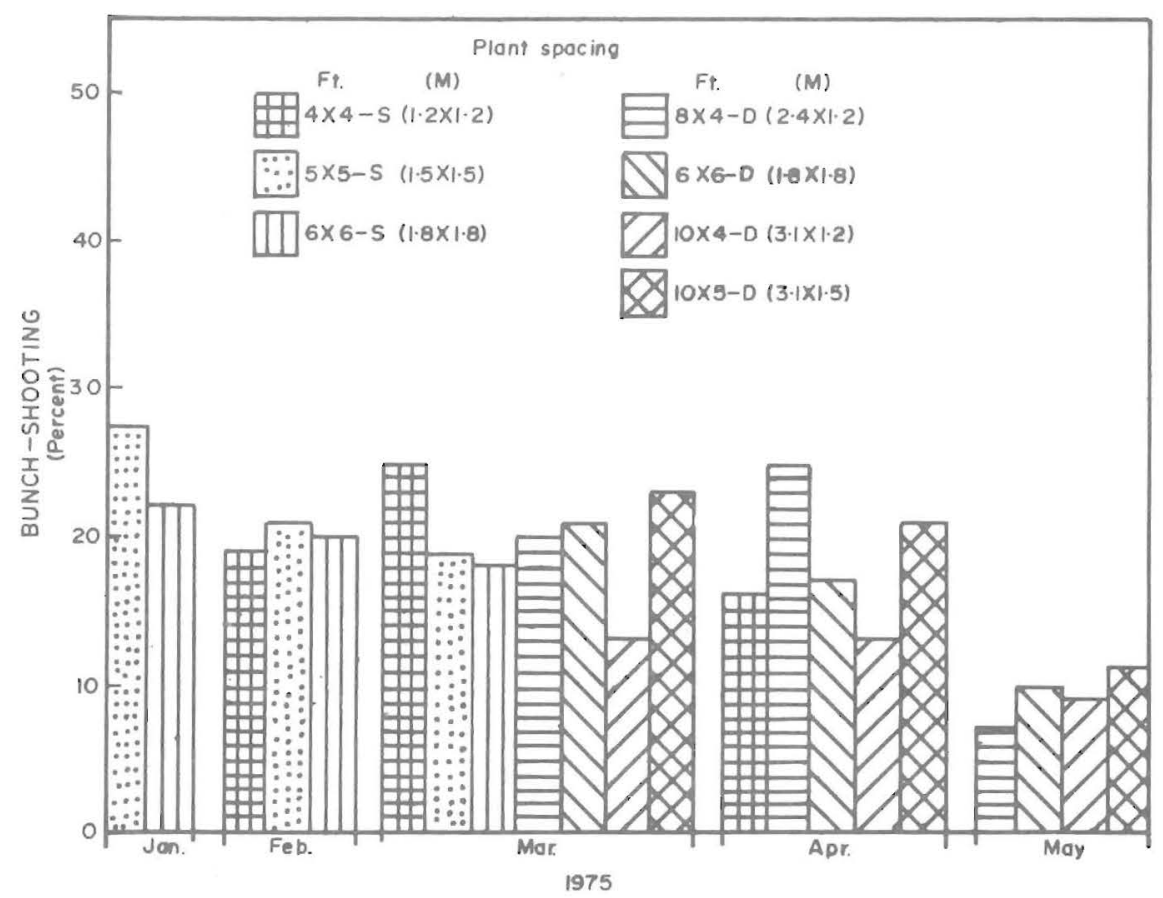

FIG. 2.-Main flowering peaks for the various plant spacings (plant crop). S, single planting; $\mathrm{D}$, double planting.

in terms of weight of fruits: 18.1 to 21.8 tons/acre ( 40.6 to 48.9 t/ha). Within each yield component, differences among these treatments were not significant. However, considering fruit quality, yield estimates for plants spaced at $4 \times 4 \mathrm{ft}(1.2 \times 1.2 \mathrm{~m})$ and, in double planting, at $8 \times 4 \mathrm{ft}$ $(2.4 \times 1.2 \mathrm{~m})$ were negligible. As expressed by number of fruits and weight/bunch as well as by weight of individual fruits (table 1), plants in both of these spacings produced bunches and fruits of inferior quality. In general, none of the double planting treatments seem to have a practical advantage over the single planting system. 
TABLE 1.-Plant crop yield of marketable bunches of Maricongo plantain in seven planting patterns at the Corozal Substation, 1975

\begin{tabular}{|c|c|c|c|c|c|c|c|c|}
\hline \multicolumn{2}{|c|}{ Plant spacing } & \multicolumn{2}{|c|}{ Number of plants } & \multicolumn{3}{|c|}{ Fruits/bunch } & \multicolumn{2}{|c|}{ Weight of individual fruits } \\
\hline \multirow{2}{*}{$F t$} & \multirow{2}{*}{$M$} & \multirow{2}{*}{ Per acre } & \multirow{2}{*}{ Perha } & \multirow{2}{*}{ Number } & \multicolumn{2}{|c|}{ Weight } & \multirow{2}{*}{$L b$} & \multirow{2}{*}{$G$} \\
\hline & & & & & $L b$ & $\mathrm{Kg}$ & & \\
\hline \multicolumn{9}{|l|}{1 plant/hole: } \\
\hline $6 \times 6$ & $1.8 \times 1.8$ & 1,210 & 2,989 & $41.9 \mathrm{a}^{1}$ & $33.9 \mathrm{a}$ & 15.3 & $0.76 \mathrm{a}$ & 345.0 \\
\hline $5 \times 5$ & $1.5 \times 1.5$ & 1,742 & 4,303 & $39.2 \mathrm{ab}$ & $27.7 \mathrm{~b}$ & 12.5 & $.69 \mathrm{ab}$ & 313.3 \\
\hline $4 \times 4$ & $1.2 \times 1.2$ & 2,723 & 6,726 & $36.1 \mathrm{bc}$ & $22.1 \mathrm{bc}$ & 9.9 & $.56 \mathrm{bc}$ & 254.2 \\
\hline \multicolumn{9}{|c|}{2 plants/hole: } \\
\hline $10 \times 5$ & $3.1 \times 1.5$ & 1,742 & 4,303 & $38.8 \mathrm{ab}$ & $25.4 \mathrm{~b}$ & 11.4 & $0.63 \mathrm{abc}$ & 286.0 \\
\hline $10 \times 4$ & $3.1 \times 1.2$ & 2,178 & 5,380 & $36.8 \mathrm{bc}$ & $18.7 \mathrm{c}$ & 8.4 & $.48 \mathrm{c}$ & 217.9 \\
\hline $6 \times 6$ & $1.8 \times 1.8$ & 2,420 & 5,977 & $39.3 \mathrm{ab}$ & $24.9 \mathrm{bc}$ & 11.2 & $.59 \mathrm{bc}$ & 267.9 \\
\hline $8 \times 4$ & $2.4 \times 1.2$ & 2,723 & 6,726 & $34.9 \mathrm{c}$ & $19.5 \mathrm{c}$ & 8.8 & $.49 \mathrm{c}$ & 222.5 \\
\hline
\end{tabular}

${ }^{1}$ Means in columns followed by one or more letters in common do not differ significantly at $\mathrm{P}=0.05$.

TABLE 2.-Plant crop yield of Maricongo plantain in seven planting patterns at the Corozal Substation, 1975

\begin{tabular}{|c|c|c|c|c|c|c|c|}
\hline \multicolumn{2}{|c|}{ Plant spacing } & \multicolumn{2}{|c|}{ Number of plants } & \multicolumn{4}{|c|}{ Yield } \\
\hline \multirow[b]{2}{*}{$F t$} & \multirow[b]{2}{*}{$M$} & \multirow[b]{2}{*}{ Per acre } & \multirow[b]{2}{*}{ Per ha } & \multicolumn{2}{|c|}{ Number of fruits } & \multicolumn{2}{|c|}{ Weight of fruits } \\
\hline & & & & Per acre & Perha & Tons/acre & $t / h a$ \\
\hline \multicolumn{8}{|c|}{1 plant/hole: } \\
\hline $6 \times 6$ & $1.8 \times 1.8$ & 1,210 & 2,989 & $47,113.6 c^{1}$ & $116,370.6$ & $19.3 \mathrm{a}$ & 43.3 \\
\hline $5 \times 5$ & $1.5 \times 1.5$ & 1,742 & 4,303 & $65,034.9 \mathrm{ab}$ & $160,636.2$ & $21.4 \mathrm{a}$ & 47.9 \\
\hline $4 \times 4$ & $1.2 \times 1.2$ & 2,723 & 6,726 & $79,113.6 \mathrm{a}$ & $195,410.6$ & $21.8 \mathrm{a}$ & 48.9 \\
\hline \multicolumn{8}{|c|}{2 plants/hole: } \\
\hline $10 \times 5$ & $3.1 \times 1.5$ & 1,742 & 4,303 & $45,679.8 \mathrm{c}$ & $112,829.1$ & $12.8 \mathrm{~cd}$ & 28.7 \\
\hline $10 \times 4$ & $3.1 \times 1.2$ & 2,178 & 5,380 & $39,537.4 \mathrm{c}$ & $97,657.4$ & $7.8 \mathrm{~d}$ & 17.5 \\
\hline $6 \times 6$ & $1.8 \times 1.8$ & 2,420 & 5,977 & $62,031.2 \mathrm{~b}$ & $153,217.1$ & $18.1 \mathrm{ab}$ & 40.6 \\
\hline $8 \times 4$ & $2.4 \times 1.2$ & 2,723 & 6,726 & $64,888.5 \mathrm{ab}$ & $160,274.6$ & $13.9 \mathrm{bc}$ & 31.2 \\
\hline
\end{tabular}

\footnotetext{
${ }^{1}$ Means in columns followed by one or more letters in common do not differ significantly at $\mathrm{P}=0.05$.
} 


\section{RATOON CROP}

The bunch-shooting peaks for each plant spacing in the second crop are shown in figure 3 . Plants spaced at $8 \times 4 \mathrm{ft}(2.4 \times 1.2 \mathrm{~m}), 6 \times 6 \mathrm{ft}(1.8$ $\times 1.8 \mathrm{~m}), 10 \times 4 \mathrm{ft}(3.1 \times 1.2 \mathrm{~m})$, and $10 \times 5 \mathrm{ft}(3.1 \times 1.5 \mathrm{~m})$ flowered earliest and simultaneously, with peaks from March through May 1976. Bunch-shooting peaks in the closer spacings of $5 \times 5 \mathrm{ft}(1.5 \times 1.5 \mathrm{~m})$ and

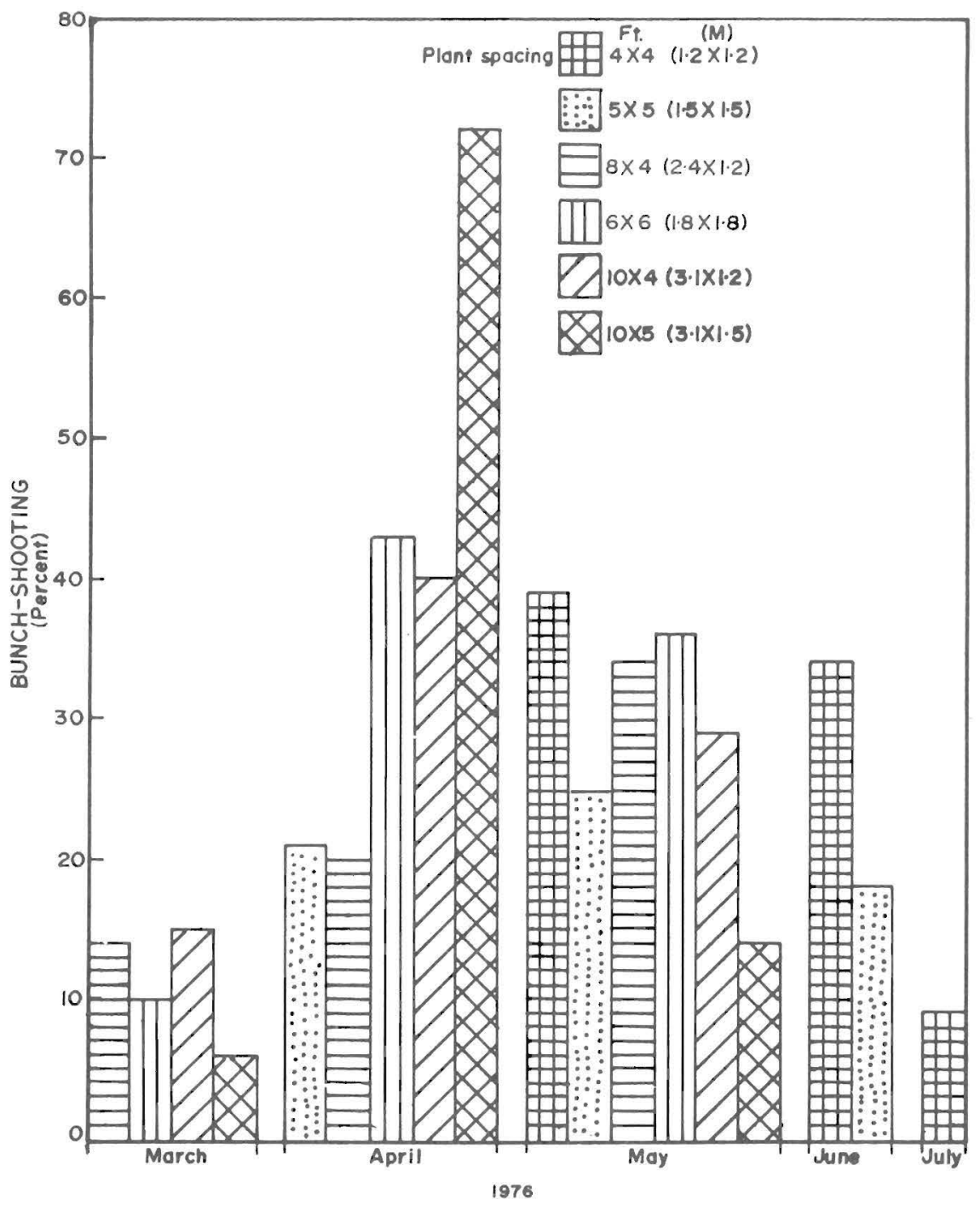

FIG. 3.-Main flowering peaks for the various plant spacings (ratoon crop). 
$4 \times 4 \mathrm{ft}(1.2 \times 1.2 \mathrm{~m})$ were delayed 1 and 2 months, lasting from April through June and from May through July 1976, respectively.

Harvesting began in June and ended on August 4, 1976, as a result of gale-force winds that followed a summer drought from May through August (fig. 1). At that time, $60.3 \%$ of the experimental plants were harvested; the spacing with the lowest percentage harvested, $22.2 \%$, was $4 \times 4 \mathrm{ft}(1.2 \times 1.2 \mathrm{~m})$ and the spacing with the highest percentage harvested, $91.4 \%$, was $10 \times 5 \mathrm{ft}(3.1 \times 1.5 \mathrm{~m})$.

Plants in all spacings except $6 \times 6 \mathrm{ft}(1.8 \times 1.8 \mathrm{~m})$ produced larger bunches (table 3 ) than their counterparts in the plant crop (table 1). The largest bunches, which averaged 41 marketable fruits and $35.3 \mathrm{lb}$ (15.9 $\mathrm{kg})$, were produced by plants spaced at $10 \times 4 \mathrm{ft}(3.1 \times 1.2 \mathrm{~m})$. Although these bunches averaged 3 marketable fruits and $8.9 \mathrm{lb}(4.0 \mathrm{~kg})$ more than those produced by plants in the closest spacing, $4 \times 4 \mathrm{ft}(1.2 \times 1.2 \mathrm{~m})$,

TABLE 3.-Ratoon crop yield of marketable bunches of Maricongo plantain in six spacings at the Corozal Substation, 1976

\begin{tabular}{|c|c|c|c|c|c|c|c|c|}
\hline \multicolumn{2}{|c|}{ Plant spacing } & \multicolumn{2}{|c|}{ Number of plants } & \multicolumn{3}{|c|}{ Fruits/bunch } & \multicolumn{2}{|c|}{$\begin{array}{c}\text { Weight of } \\
\text { individual fruits }\end{array}$} \\
\hline & & & & \multirow[t]{2}{*}{ Number } & \multicolumn{2}{|c|}{ Weight } & & \\
\hline$F t$ & $M$ & Per acre & Perha & & $L b$ & $\mathrm{Kg}$ & $L b$ & $G$ \\
\hline $10 \times 5$ & $3.1 \times 1.5$ & 871 & 2,151 & $40.7 \mathrm{a}^{1}$ & $32.8 \mathrm{a}$ & 14.8 & $0.72 \mathrm{~b}$ & 325.0 \\
\hline $10 \times 4$ & $3.1 \times 1.2$ & 1,089 & 2,690 & $41.4 \mathrm{a}$ & $35.3 \mathrm{a}$ & 15.9 & $.83 \mathrm{a}$ & 377.8 \\
\hline $6 \times 6$ & $1.8 \times 1.8$ & 1,210 & 2,989 & $38.1 \mathrm{a}$ & $28.3 \mathrm{a}$ & 12.7 & $.70 \mathrm{~b}$ & 315.7 \\
\hline $8 \times 4$ & $2.4 \times 1.2$ & 1,361 & 3,362 & $41.0 \mathrm{a}$ & $28.8 \mathrm{a}$ & 13.0 & $.68 \mathrm{~b}$ & 310.6 \\
\hline $5 \times 5$ & $1.5 \times 1.5$ & 1,742 & 4,303 & $37.9 \mathrm{a}$ & $29.2 \mathrm{a}$ & 13.1 & $.77 \mathrm{ab}$ & 351.4 \\
\hline $4 \times 4$ & $1.2 \times 1.2$ & 2,723 & 6,726 & $37.5 \mathrm{a}$ & $26.4 \mathrm{a}$ & 11.9 & $.71 \mathrm{~b}$ & 322.8 \\
\hline
\end{tabular}

${ }^{1}$ Means in columns followed by one or more letters in common do not differ significantly at $\mathrm{P}=0.05$.

this difference was not statistically significant. The heaviest individual fruits, $0.83 \mathrm{lb}(377 \mathrm{~g})$ were also produced by plants spaced at $10 \times 4 \mathrm{ft}(3.1$ $\times 1.2 \mathrm{~m}$ ); these fruits were significantly heavier than all others except those produced by plants spaced at $5 \times 5 \mathrm{ft}(1.5 \times 1.5 \mathrm{~m})$.

In terms of number of fruits, yield increased with increasing population density (table 4). The yields of 69,906 fruits/acre (172,667 fruits/ha) produced by plants in the closest spacing, $4 \times 4 \mathrm{ft}(1.2 \times 1.2 \mathrm{~m})$, was significantly higher than that for plants in any other spacing. However, because of the low number of marketable bunches and low bunch and individual fruit weights for plants at this spacing, their yield in terms of weight was only 7 tons of fruits/acre $(15.7 \mathrm{t} / \mathrm{ha})$ compared with that for plants spaced at $10 \times 4 \mathrm{ft}(3.1 \times 1.2 \mathrm{~m})$ and $6 \times 6 \mathrm{ft}(1.8 \times 1.8 \mathrm{~m})$, which yielded 14.8 and 13.2 tons/acre (33.2 and 29.6 t/ha), respectively.

The generally higher bunch and individual fruit weights in the ratoon 
crop compared with the plant crop may be attributed in part to adequate rainfall after desuckering on August 21, 1975, and through April 1976 (fig. 1). The adequate rainfall probably explains the early peak harvest, about 11 months after desuckering. The only dry spell during the development of the ratoon crop was from May through August 1976, coinciding with the late stage of bunch-shooting and the harvest. As a result, the plants late in flowering were probably the most affected by the dry spell.

In contrast, the plant crop was subjected to two dry spells (fig. 1). Subnormal rainfall during the first 5 months after planting (February through June 1974) was followed by normal rainfall through January 1975, but then another drought coincided with the bunch-shooting and harvesting stages. It was probably partly for this reason that the plant crop took 17 months to complete the cycle from planting to harvest peak.

Under the conditions of this experiment the highest yields of the Maricongo plantain were obtained with 1,742 plants/acre (4,303 plants/

TABLE 4.-Ratoon crop yield of Maricongo plantain in six spacings at the Corozal

Substation, 1976

\begin{tabular}{|c|c|c|c|c|c|c|c|}
\hline \multirow{2}{*}{\multicolumn{2}{|c|}{ Plant spacing }} & \multirow{2}{*}{\multicolumn{2}{|c|}{ Number of plants }} & \multicolumn{4}{|c|}{ Yield } \\
\hline & & & & \multicolumn{2}{|c|}{ Number of fruits } & \multicolumn{2}{|c|}{ Weight of fruits } \\
\hline$F t$ & $M$ & Per acre & Per ha & Per acre & Perha & Tons/acre & t/ha \\
\hline $10 \times 5$ & $3.1 \times 1.5$ & 871 & 2,151 & $31,344.2 \mathrm{e}^{1}$ & $77,420.2$ & $12.5 \mathrm{ab}$ & 28.0 \\
\hline $10 \times 4$ & $3.1 \times 1.2$ & 1,089 & 2,690 & $41,247.4 \mathrm{~d}$ & $101,881.1$ & $14.8 \mathrm{a}$ & 33.2 \\
\hline $6 \times 6$ & $1.8 \times 1.8$ & 1,210 & 2,989 & $44,599.0 \mathrm{~cd}$ & $110,159.5$ & $13.2 \mathrm{a}$ & 29.6 \\
\hline $8 \times 4$ & $2.4 \times 1.2$ & 1,361 & 3,362 & $51,555.0 \mathrm{bc}$ & $127,340.9$ & $11.7 \mathrm{ab}$ & 26.2 \\
\hline $5 \times 5$ & $1.5 \times 1.5$ & 1,742 & 4,303 & $54,321.0 \mathrm{~b}$ & $134,172.9$ & $12.0 \mathrm{ab}$ & 26.9 \\
\hline $4 \times 4$ & $1.2 \times 1.2$ & 2,723 & 6,726 & $69,905.5 \mathrm{a}$ & $172,666.6$ & $7.0 \mathrm{~b}$ & 15.7 \\
\hline
\end{tabular}

${ }^{1}$ Means in columns followed by one or more letters in common do not differ significantly at $\mathrm{P}=0.05$.

ha) spaced at $5 \times 5 \mathrm{ft}(1.5 \times 1.5 \mathrm{~m})$, with no reduction of bunch or fruit size. With this spacing the plant crop produced 65,035 marketable fruits/ acre or 21.4 tons/acre $(160,636$ fruits/ha or $47.9 \mathrm{t} / \mathrm{ha})$. Such yields are comparable to those reported by Irizarry et al. ${ }^{6}$ for a similar spacing and population density at the Corozal Substation.

Combined production from the first and second crops was 119,356 marketable fruits/acre or 33.4 tons/acre $(294,809$ fruits/ha or $73.5 \mathrm{t} / \mathrm{ha}$ ) over a 30-month period (February 1974 through August 1976). However, it is assumed, that in practice $20 \%$ of the crop will be lost for various reasons and a net production of 95,485 marketable fruits/acre or 26.7 tons/acre $(235,847$ fruits/ha or $58.7 \mathrm{t} / \mathrm{ha})$ is a reasonable expectation.

\section{RESUMEN}

Se evaluaron varios sistemas y densidades de siembra con plátanos en la Subestación de Corozal. Estas fueron por acre o hectárea: $6 \times 6$ pies $(1.8 \times 1.8 \mathrm{~m}), 1,210$ plantas $(2,989$ 
plantas/ha); $5 \times 5$ pies $(1.5 \times 1.5 \mathrm{~m}), 1,742$ plantas $(4,303$ plantas $/$ ha $) ; 4 \times 4$ pies $(1.2 \times 1.2$ $\mathrm{m}), 2,722$ plantas, $(6,723$ plantas/ha) y dos hijos por hoyo con distancias de $10 \times 5$ pies $(3.1$ $\times 1.5 \mathrm{~m})$ 1,742 plantas, $(4,303$ plantas $/ \mathrm{ha}) ; 10 \times 4$ pies $(3.1 \times 1.2 \mathrm{~m}), 2,178$ plantas $(5,380$ plantas/ha); $6 \times 6$ pies $(1.8 \times 1.8 \mathrm{~m}), 2,420$ plantas $(5,977$ plantas/ha $) ;$ y $8 \times 4$ pies $(2.4 \times 1.2$ m), 2,723 plantas $(6,726$ plantas/ha).

Después de la cosecha de plantilla los tratamientos de doble semilla se redujeron a una planta por hoyo con densidades por acre o hectárea de: $8 \times 4$ pies $(2.4 \times 1.2 \mathrm{~m}), 1,361$ plantas $(3,362$ plantas $/$ ha $) ; 10 \times 4$ pies $(3.1 \times 1.2 \mathrm{~m}), 1,089$ plantas $(2,690$ plantas $/$ ha $)$ y 10 $\times 5$ pies $(3.1 \times 1.5 \mathrm{~m}), 871$ plantas $(2,151$ plantas $/ \mathrm{ha})$.

El experimento se abonó con un fertilizante $10-5-20$ que además contenía $166 \mathrm{lb}(75.3 \mathrm{~kg})$ de $\mathrm{MgO}$ y $100 \mathrm{lb}(45.4 \mathrm{~kg}$ ) de otros oligoelementos/tonelada. La plantilla se abonó a los 2, 5 y 9 meses de edad y el retoño 1 y 5 meses después del deschuponado. En total se aplicaron $2 \mathrm{lb}(.9 \mathrm{~kg})$ de abono por planta o cepa para la cosecha de plantilla y $1.4 \mathrm{lb}(.6 \mathrm{~kg})$ para la de retoño.

A mayor densidad de siembra más largo fue el ciclo de siembra a cosecha. En la plantilla, la siembra a $6 \times 6$ pies $(1.8 \times 1.8 \mathrm{~m}), 1,210$ plantas/acre $(2,989$ plantas/ha) produjo los mejores racimos tanto en número de plátanos como en peso. En la cosecha de retoño, sin embargo, la siembra a $10 \times 4$ pies $(3.1 \times 1.2 \mathrm{~m}), 1,089$ plantas/acre $(2,690$ plantas/ha $)$ produjo los racimos de mayor tamaño, pero la diferencia no fue estadísticamente significativa.

Tomando en cuenta los rendimientos de la primera y segunda cosechas, puede concluirse que la producción máxima que se puede obtener sin que se afecte el tamaño tanto del racimo como de la fruta, es sembrando a $5 \times 5$ pies $(1.5 \times 1.5 \mathrm{~m}), 1,742$ plantas/acre $(4,303$ plantas/ha).

Dado que en la práctica se pierda el $20 \%$ de la cosecha, la producción combinada de ambas seria de 95,000 frutas comerciales, que representan 16 toneladas de pulpa húmeda ó 6.4 toneladas de pulpa seca/acre $(234,650$ frutas, $35.2 \mathrm{Tm}$. de pulpa fresca ó $14.1 \mathrm{Tm}$. de pulpa seca/ha) en un periodo de 30 meses. 